\title{
Estimation of Surface Normal Vector Based on Majority Voting using Multi-Light Photometric Stereo
}

\author{
Hisao Fukumoto Member (Saga University, fukumoto@dna.ec.saga-u.ac.jp) \\ Hiroshi Terashima Non-member (Saga University, terasima@dna.ec.saga-u.ac.jp) \\ Masashi Ohchi Senior Member (Chiba Institute of Technology, masashi.ohchi@it-chiba.ac.jp) \\ Tatsuya Furukawa Member (Saga University, tach@ace.ec.saga-u.ac.jp)
}

Keywords: photometric stereo, specular reflection, linear least-squares, multi-light source

In this paper, we present an algorithm for estimating the surface normal vector of an object from images using multilight source photometric stereo in the presence of highlights and shadows.

Woodham et.al. proposed the photometric stereo to determine the surface shape of an object using multiple images that was taken with the same viewpoint under the condition of different three or more light sources. The differences in the intensities of the images depend on the surface orientation of object. It is estimated surface normal vector by combining the intensities from all images.

Specularity and shadowing influence reconstructing object shape for the traditional three-light source photometric stereo because of its assumptions of a Lambertian surface and local shading. A number of methods have been developed to recover the shape of specular objects using multilight source.

We propose strategy to eliminate the effects of specularity and shadowing using an algorithm of majority voting in the multi-light photometry. In this method, surface normal vectors are calculated by three-light photometric for every possible triplet combination using eight-light source without shadowing.

There are ${ }_{8} C_{3}=56$ combinations of triplet illumination by using eight-light source. If the specular region is illuminated by only one light source, obtained ${ }_{7} C_{2}=21$ of surface normal vectors are doubtful data. The 56 of surface normal vectors are voted in the azimuth-zenith space. The 21 of doubtful data of surface normal vectors are distributed in wide area of azimuth-zenith space as shown in Fig. 1. Therefore, remaining surface normal vectors, that are not affected by specularity, present a peak in the azimuth-zenith space. The surface normal vectors of the peak are recalculated by linear least-squares using light sources that are required by each three-light photometric stereo in these normal vectors.

We compared three methods, Method1; linear leastsquares of eight intensity values under eight light sources, Method2; eliminating the highest and lowest intensity and

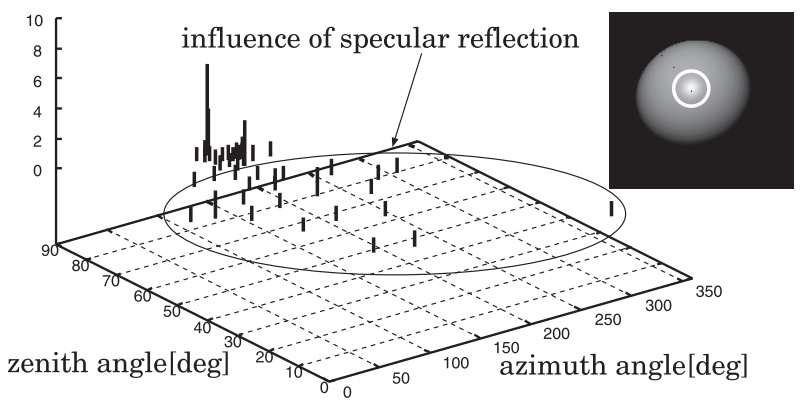

(a) specular reflection point

Fig. 1. Examples of distribution of normal vectors in the azimuth and zenith space at specular reflection points of sphere

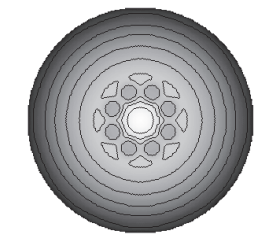

(a) Method 1

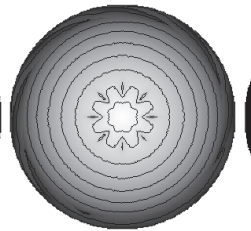

(b) Method2

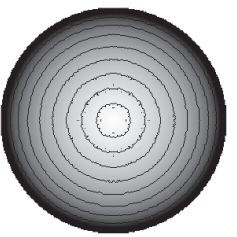

(c) Method3

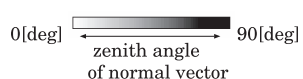

Fig. 2. Distribution of zenith angle of estimated normal vector of sphere in simulation

Method3; our proposal method. The intensity values in a shadow area will tend to be very low. On the other hand, in a highlight area, the effect of specular reflection will tend to be very high intensity values. Figure 2 shows the distribution of zenith angle of estimated surface normal vectors of sphere in simulation. It is clear that the Method 1 and Method2 failed to remove the effects of specularity. The experimental results using real ball agree approximately with these simulated results. The proposed method improves the accuracy of estimating surface normal vector. 


\title{
多光源照度差ステレオ法における投票・多数決による 物体表面法線ベクトルの推定
}

\author{
正 員 福本 尚生* 非会員 寺島 広志* \\ 上級会員 相知 政司** 正 員 古川 達也* \\ Estimation of Surface Normal Vector Based on Majority Voting
using Multi-Light Photometric Stereo \\ Hisao Fukumoto*, Member, Hiroshi Terashima*, Non-member, \\ Masashi Ohchi**, Senior Member, Tatsuya Furukawa*, Member
}

\begin{abstract}
In this paper, we present an algorithm for estimating surface normal vectors of object from images using multi-light source photometric stereo method in the presence of highlights and shadows. The conventional three-light photometric stereo can not deal with specularity and shadowing because of its simple assumption of a Lambertian surface and local shading. By high intensity or low intensity values, the specular reflection and shadowing will produce an incorrect surface normal in the traditional photometric stereo. We propose a new strategy to eliminate the effects of specularity and shadowing using an algorithm of majority voting in the multi-light source photometry.
\end{abstract}

キーワード：照度差ステレオ法, 鏡面反射, 最小二乗法, 多光源

Keywords: photometric stereo, specular reflection, linear least-squares, multi-light source

\section{1. はじめに}

近年，物体形状の簡便な計測手法の要求が高まってきて いる。工業製品の開発, 設計においても CAD データの利用 が盛んに行われており, 試作品や既成の製品形状から CAD データに変換することによって, 物作りの効率化やコスト 削減につながる。これまでに, 物体形状を非接触で計測す る様々な手法が提案されている(1)。

物体にスリットビームや形が既知の光を照射し計測する 方法では, 一般的に光を照射する装置が複雑かつ高価であ る。複数台のカメラを用いたステレオ法では, 2 台以上のカ メラによって物体を撮影し，物体が撮影された画像上の位 置から, 三角測量の原理で物体までの距離を求める。この 手法では, 複数の画像における物体の対応関係を求める必 要があるが，表面に模様のないテクスチャレスの物体に対 しては, 対応を求めることが困難であると共に, 複数のカ

\footnotetext{
* 佐賀大学理工学部電気電子工学科

于 840-8502 佐賀市本庄町 1 番地

Faculty of Science and Engineering, Saga University

1, Honjo-machi, Saga 840-8502

** 千葉工業大学工学部電気電子情報工学科

275-0016 千葉県習志野市津田沼 2-17-1

Faculty of Engineering, Chiba Institute of Technology

2-17-1, Tsudanuma, Narashino, Chiba, 275-0016
}

メラにより物体を撮影するために，一部の画像に映ってい る領域が他の画像では物体の影に隠れて映っていない場合 には対応を求めることができない，オクルージョンの問題 等がある。視体積交差法 ${ }^{(2)}$ と呼ばれる手法では, 複数のカ メラから得られるシルエットから物体の形状を求める。こ の方法では, テクスチャレスの物体に対しても, 形状を求 めることが可能ではあるが, 原理上, 物体の凸状の形状は シルエットとして観測されるが, 凹面を計測することは難 しい。

本研究で筆者らは, 照度差ステレオ法に着目した。照度 差ステレオ法とは, Woodham ${ }^{(3)}$ らが提案した手法で, 三 つ以上の異なる光源を順次照明して得られる複数枚の画像 によって, その画像の濃淡值を基に物体表面の法線べクト ルを求める手法である。表面法線ベクトルが求められると, 積分等の処理を経て物体形状の復元が可能である。1 台の力 メラによって画像を取得するため, ステレオ法のように画 像間の対応を求める必要がなく, 物体表面がテクスチャレ スであっても形状を求めることが可能である。さらに，物 体を照明する光源の方向を変えるだけであるので，レーザ 光等を走査するような特別な機構も必要ない。

照度差ステレオ法における問題点として, 影や表面の反 射特性の問題がある。 3 光源照度差ステレオによる精度の 良い形状復元には, 大きく異なる光源方向での配置が必要 
であるが，物体形状によっては影の領域が増加し，3 光源 によって共通して照明される領域も減り，共通して照明さ れる領域以外では，形状を正確に復元することができない。 また，通常は Lambert の表面反射特性を仮定しているこ とから，鏡面反射を起こすような物体の復元は不可能であ る(4)。そこで，多光源を用いる手法が提案されている。四 つの光源を用いた手法 ${ }^{(5)(6)}$ では, 4 光源のうちから, 全て の三つの光源の組み合わせ (この場合 $\left.{ }_{4} C_{3}=4\right)$ で照度差 ステレオの計算を行い，得られた四つの表面反射率のうち， 最も小さいものを選択する。これは，一つの光源による画 像だけに鏡面反射成分が含まれていると仮定すると，鏡面 反射の影響を受けない光源の組み合わせでは, 最小の表面 反射率を示すことを利用している。S.Barsky ら (7) は, 最 小二乗法により鏡面反射と影の影響を小さくする最も簡単 な手法を提案している。

H.Rushmeier ら ${ }^{(8)}$ は 5 光源による手法を提案している。 五つの光源で照明された点の各輝度值を大きいものからソー ティングし, 最大值, 最小值を除いた三つの輝度值を利用 して照度差ステレオを解くという手法である。輝度の最大 值は鏡面反射, 輝度の最小值は影の影響の可能性があると して排除している。6 光源による手法 ${ }^{(9)}$ も提案されている が，基本的な考え方は H.Rushmeier らの考え方と同じで ある。しかしながら，鏡面反射の影響が一つの光源に収ま らない場合も考えられ，そのような場合には，これらの手 法は最適とは言えない。また，多くの手法(5) (7) (9) で, 実 際には鏡面反射を区別するために，複数光源により得られ た反射率の分散等を基にした閾值処理を行っており，閾值 の設定によって結果が左右される。本研究では，鏡面反射 や影の影響を除去する手法として, 新たに投票・多数決に よる手法を提案する。本提案手法では，鏡面反射を判定す る閾值を理論的には設定する必要がない。シミュレーショ ンと実駼結果から, H.Rushmeier らによって提案されてい る手法と比較しても本手法が有効であることを示す。

\section{2. 照度差ステレオ法}

物体表面が拡散反射だけを起こす拡散反射表面である と仮定し，その表面の反射率を $k_{d}$ と㧍く。さらに，照明 する光源は平行光源を仮定し, 光源の単位方向ベクトルを $\boldsymbol{S}\left(s_{x}, s_{y}, s_{z}\right)^{T}$ とする。物体表面のある点の単位法線べク

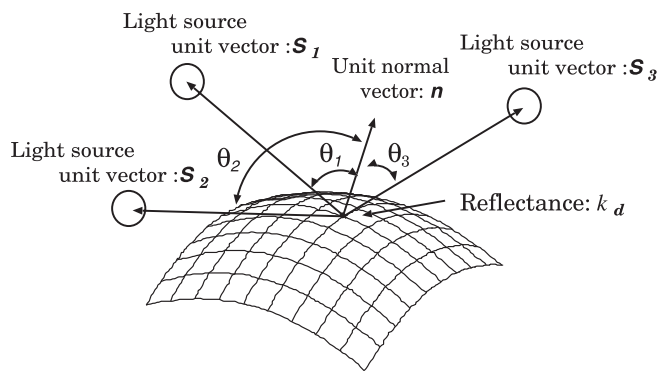

Fig. 1. Photometric stereo method.
トルを $\boldsymbol{n}\left(n_{x}, n_{y}, n_{z}\right)^{T}$ ，その点に扔ける物体の明るさを $I_{d}$ とすると，

$$
I_{d}=k_{d} \times(\boldsymbol{S} \cdot \boldsymbol{n})=k_{d} \cos (\theta)
$$

で表すことができる。ここで・は内積の演算を示す。照 度差ステレオ法では, Fig. 1 に示すように, 三つ以上 $(m \geq 3)$ の光源により物体を照明するために, 光源方 向べクトル $\boldsymbol{S}_{1}, \boldsymbol{S}_{2}, \ldots, \boldsymbol{S}_{m}$ により構成される行列 $\boldsymbol{L}=$ $\left(\boldsymbol{S}_{1}, \boldsymbol{S}_{2}, \ldots, \boldsymbol{S}_{m}\right)^{T}$ が得られる。また，各光源より照明さ れた時に計測される各画素点の明るさ $I$ にるべクトル $\boldsymbol{I}=\left(I_{1}, I_{2}, \ldots, I_{m}\right)^{T}$ を考えることができる。

(1) 式が, $m$ 個の光源抢よび物体の明るさのそれぞれで 成り立つので，それらを連立させた式は，

$$
\boldsymbol{I}=k_{d} \times(\boldsymbol{L} \boldsymbol{n})
$$

のように書ける。これは，擬似逆行列 $L^{+(10)}$ を用いて，

$$
k_{d} \boldsymbol{n}=L^{+} \boldsymbol{I}=\left(\boldsymbol{L}^{T} \boldsymbol{L}\right)^{-1} \boldsymbol{L}^{T} \boldsymbol{I} .
$$

が得られ， $|\boldsymbol{n}|=1$ であるので，

$$
\begin{aligned}
& k_{d}=\left|\left(\boldsymbol{L}^{T} \boldsymbol{L}\right)^{-1} \boldsymbol{L}^{T} \boldsymbol{I}\right| \\
& \boldsymbol{n}=\left(\left(\boldsymbol{L}^{T} \boldsymbol{L}\right)^{-1} \boldsymbol{L}^{T} \boldsymbol{I}\right) / k_{d}
\end{aligned}
$$

のように表面反射率と物体表面法線ベクトルを最小二乗法 的に求めることができる ${ }^{(9)}$ 。

〈2・1〉 表面の反射 プラスチックに代表される物体 の表面は二色性反射モデルがよく使用される。このモデル はコンピュータグラフィックスの分野等における Phong の 反射モデルに対応する ${ }^{(11)}$ 。物体から反射される光 $I$ は二 つの異なる成分による線形結合で記述可能であると仮定し， 以下の式で表現する。

$$
I=I_{d}+I_{s}
$$

Fig. 2 に表面反射モデルの説明図を示す。拡散反射光成分 $I_{d}$ は Lambert の法則によって定義される。(1) 式のよう に, 物体から反射される光の明るさは, 反射が起こる面の 単位法線ベクトル $\boldsymbol{n}$ と, 物体を照明する光源の単位方向べ クトル $\boldsymbol{S}$ の内積によって決定される。ここで $k_{d}$ は物体固 有の拡散反射率である。Phong の反射モデルでは, 鏡面反 射光成分 $I_{s}$ は先に述べた, 反射が扔こる面の単位法線べク トル $\boldsymbol{n}$ と, 光源の単位方向ベクトル $\boldsymbol{S}$ に加えて, 視点方

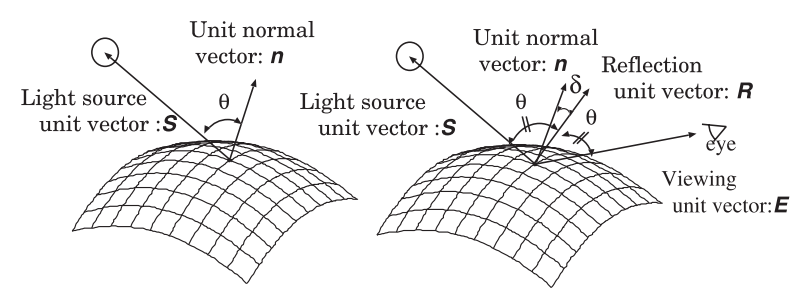

(a) Diffuse reflection

(b) Specular reflection

Fig. 2. Reflectance model. 
向の単位ベクトル $\boldsymbol{E}$ が必要になる。光源方向の単位べクト ル $\boldsymbol{S}$ と視点方向の単位ベクトル $\boldsymbol{E}$ のなす角を二等分する 単位ベクトル $\boldsymbol{R}$ を求める。このベクトル $\boldsymbol{R}$ と面の単位法 線ベクトル $\boldsymbol{n}$ のなす角を $\delta$ とおくと，

$$
I_{s}=k_{s} \times(\boldsymbol{R} \cdot \boldsymbol{n})^{j}=k_{s} \times \cos (\delta)^{j} \cdots
$$

と書ける。ここで $k_{s}$ は物体固有の鏡面反射率を示す。ま た， $j$ はべき乗の係数であり，物体表面の材質によって決 定される鏡面反射の輝点の大きさを示し，光沢度である。

$\langle 2 \cdot 2\rangle$ 鏡面反射及び影の影響の除去法 前節でも述べ たように，照度差ステレオ法において表面の鏡面反射，影 の問題が生じる。本研究では, 投票・多数決による手法を 新たに提案する。光源を多数使用する場合, 光源の配置に ついては考慮する必要があるが, 光源の配置が大きく異な る場合には，鏡面反射を生じる光源（以下不適光源と称す る）は少数の光源に限られる。また, 多くの光源を使用す ることにより, 全く光が照射されない領域が減り, 影の影 響も抑えることができる。

本手法では，使用する全ての光源の中から，それぞれ三 つの組み合わせを選択し照度差ステレオの計算を行い，表 面法線べクトルを求める。八つの光源を使用した場合は
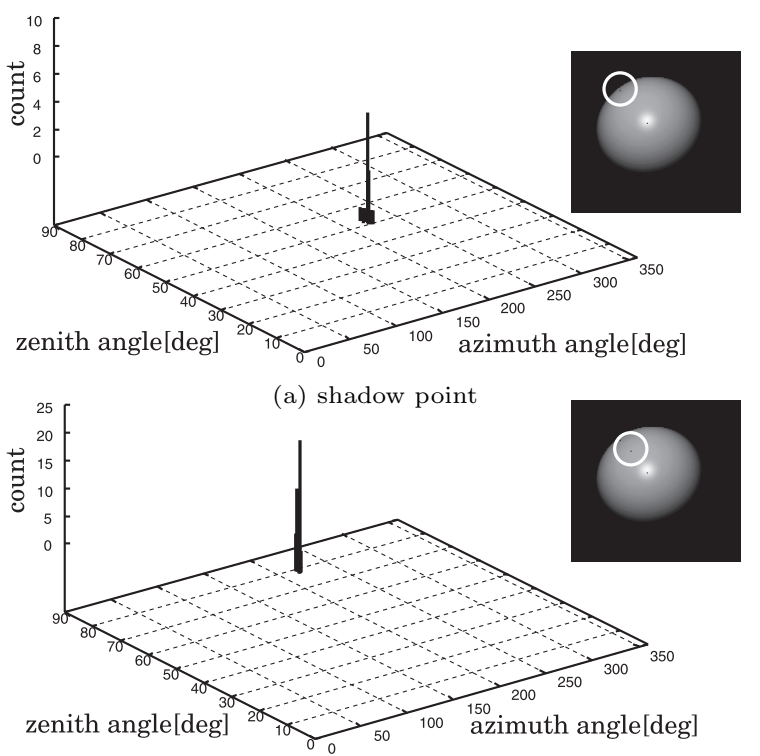

(b) diffuse reflection point

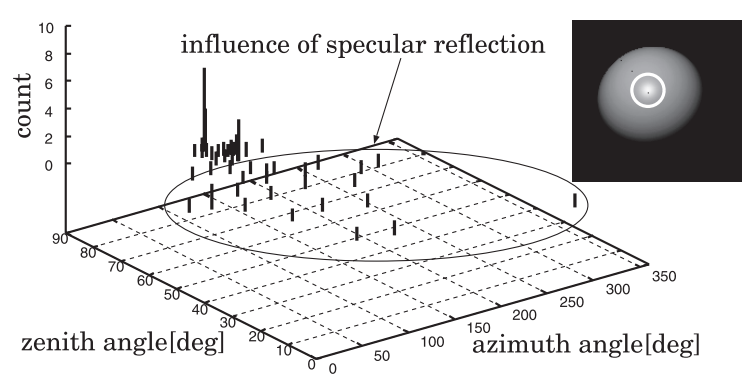

(c) specular reflection point

Fig. 3. Examples of distribution of normal vectors in the azimuth and zenith space at each point of surface.
${ }_{8} C_{3}=56$ 個の組み合わせが考えられる。また，影の影響を 抑えるために, 画像において輝度值が著しく低い光源は組 み合わせから除外している。照度差ステレオ法により求め た表面法線ベクトルから，その天頂角，方位角を求め，天 頂角，方位角からなる空間（パラメータ空間）上に表面法 線ベクトルを投票することを考える。

Fig. 3 に得られた表面法線ベクトルをパラメータ空間上 に投票した例を示す (パラメータ空間は 90 (天頂角) $\times 360$ (方位角))。図では, 光源数 8 個の場合における, 影の影 響のある点 $(\mathrm{a})$, 拡散反射だけからなる点 $(\mathrm{b})$, 鏡面反射の 影響のある点 $(\mathrm{c})$ の三つについて示している。

(a) の場合，影となっている光源を除いているために，全 体の投票数は少なくなっているが，影の影響なく一つのピー クを形成している。(b) の場合, 鏡面反射, 影の影響がなけ れば，パラメータ空間中の一点にピークをつくる。(c) の場 合，不適光源を 1 個と仮定すると ${ }_{7} C_{2}=21$ 個の表面法線 ベクトルは鏡面反射の影響を受けていると考えられる。そ れら 21 個の表面法線ベクトルは空間上に広くばらばらに 分布し, 他の $56-21=35$ 個の表面法線ベクトルは鏡面 反射の影響がないため，パラメータ空間上の一点に集中す ることになる。従って, 全ての光源の組み合わせにより得 られた表面法線べクトルが投票されたパラメータ空間上で, 多数を示すものを選択する。選択された一点に所属するそ れぞれの表面法線ベクトルについて，これらを求める際に 利用した光源の全てを用いて, 再度, 最小二乗法的に法線 ベクトルを求める。このようにすることによって，外乱の 影響を抑えることができる。

以下では, 本提案手法と従来の手法（最小二乗法だけ, 最 大值・最小值を除く手法）との比較を行った。

\section{3. シミュレーション}

〈3・1〉撮影条件＼cjkstart実験及びシミュレーションにおける 撮影条件を Fig. 4 に示す。光源からの光は平行光を仮定し, 光源の配置は Fig. 4 の座標系における, 天頂角 $\alpha$, 方位角 $\beta$ で表記する。物体としては, 理論的な法線方向が求めら れる球を対象物体とした。シミュレーションでは，仮想的 な球を生成し, 照射する光源位置を変化させて画像を作成

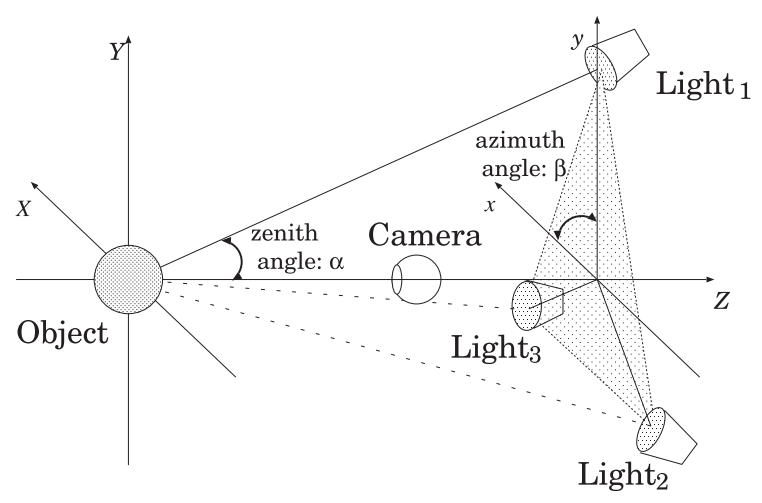

Fig. 4. Experimental condition. 


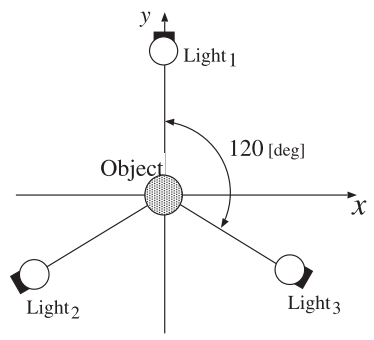

(a) Number of light Sources $=3$

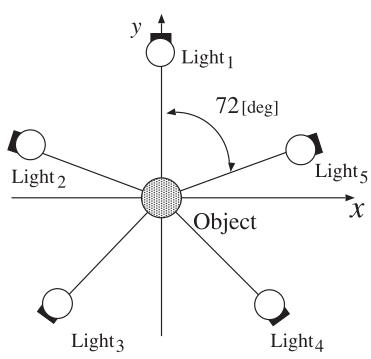

(c) Number of light Sources $=5$

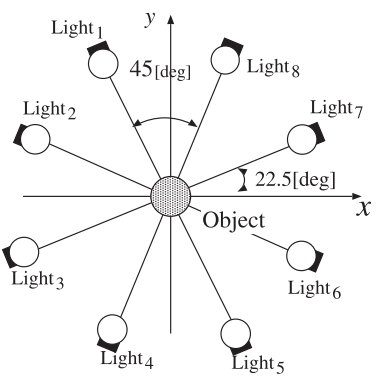

(e) Number of light Sources $=8$

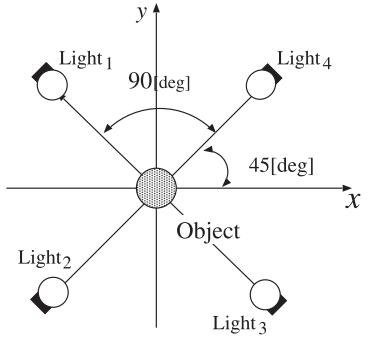

(b) Number of light Sources $=4$

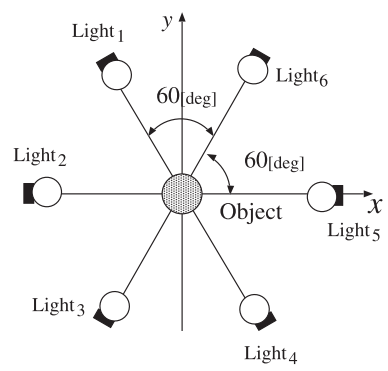

(d) Number of light Sources $=6$

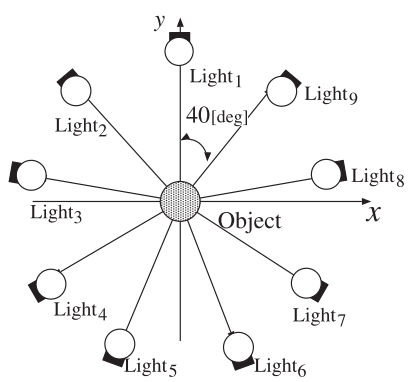

(f) Number of light Sources $=9$

Fig. 5. Light position of each light source number.

した。物体表面の反射モデルについては Phong のモデル を用い，鏡面反射のある場合について検討を行った。この 時, Phong のモデル，(1)，(6)，(7) 式のパラメータとし て, 実験結果の画像を参考に拡散反射成分を $k_{d}=120$ と し，鏡面反射成分は $k_{s}=200$ とした。また，物体の材質 によって決まる鏡面反射の輝点の大きさを決定する係数を $j=300$ とした。

光源の配置については, 光源の天頂角を $\alpha=30[\mathrm{deg}]$ と 固定し，方位角 $\beta$ を，使用する光源数に応じて Fig. 5 のよ うに設定した。上記パラメータに打いて，8光源の場合の各 画像を Fig. 6 に示す。後述する実験により撮影された球の 画像を参考に，球の半径を 115 [pixel] とし，明るさが 256 段階の 8 bit の画像を作成した。

〈3・2〉 評価方法 照度差ステレオ法により物体表面 法線べクトルを推定する際に，前述した最小二乗法だけを 用いた場合 (手法 1), 最大輝度值と最小輝度值を除いて最 小二乗法を行う手法 (手法 2), 本研究で提案する手法 (手 法 3）の三つを用いて推定結果の比較を行った。推定誤差 については，各手法により推定された法線べクトル $\boldsymbol{n}_{e}$ と, 理論的に求められた法線ベクトル $\boldsymbol{n}_{t}$ の内積で評価した。球 内部に扔ける内積の平均を求め以下の式で誤差を定義した。

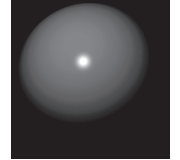

(a) $\beta=112.5$

[deg]

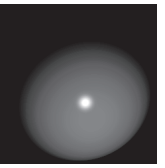

(e) $\beta=292.5$

[deg]

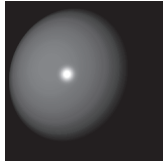

(b) $\beta=157.5$

[deg]

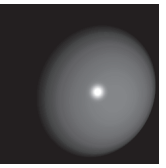

(f) $\beta=337.5$ [deg]

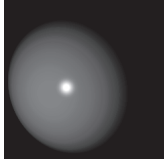

(c) $\beta=202.5$

[deg]

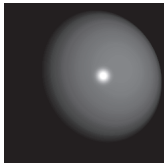

(g) $\beta=22.5$ [deg]

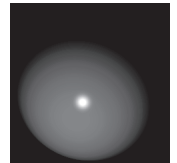

(d) $\beta=247.5$ [deg]

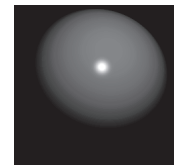

(g) $\beta=67.5$ [deg]
Fig. 6. Pictures of sphere provided specular surface with different light source direction in simulation.

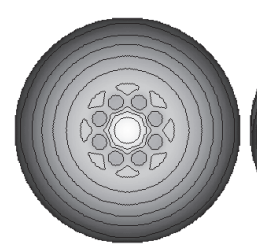

(a) Method1

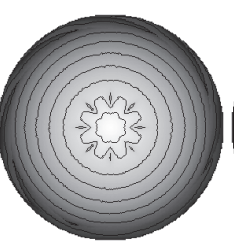

(b) Method2

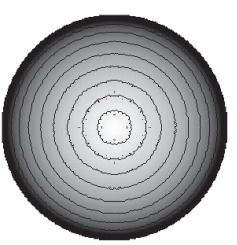

(c) Method3

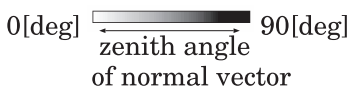

Fig. 7. Distribution of zenith angle of estimated normal vector in simulation.

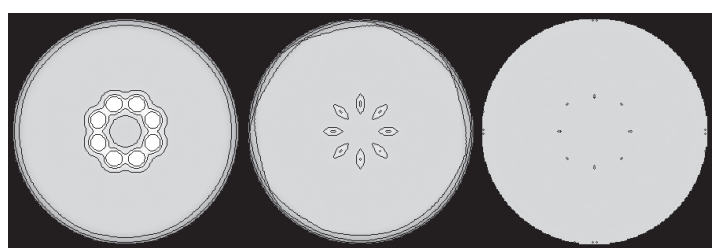

(a) Method1

(b) Method2

(c) Method3

$$
0.0 \underset{\text { Reflectance }}{\leftrightarrows} 0.6
$$

Fig. 8. Distribution of estimated object reflectance in simulation.

$$
e r r=\frac{1}{N} \sum \cos ^{-1}\left(\boldsymbol{n}_{\boldsymbol{e}} \cdot \boldsymbol{n}_{\boldsymbol{t}}\right) \quad[\mathrm{deg}]
$$

ここで, $N$ は球領域内画素数である。

$\langle\mathbf{3} \cdot 3\rangle$ 結 果 それぞれの手法で推定された物体 表面の法線ベクトルから, 天頂角を求めその分布を Fig. 7 に，表面の反射率を推定したものを Fig. 8 に示す。Fig. 7, Fig. 8 の黑い線は等高線を示している。また，表面の反射 率は一定の值を取ることが望ましい。Fig. 8 より，最小二 乗法だけを用いた手法 1 では, 鏡面反射部分の表面反射率 が他よりも高く推定されていることが分かる。したがって， Fig. 7 に拈いて，鏡面反射部分で誤差が生じている。手法 2 においては，各輝度值が最大值，最小值を示す光源を除い て計算しているにもかかわらず，鏡面反射の影響が一つの 光源で収まっていないために，推定結果に鏡面反射の影響 


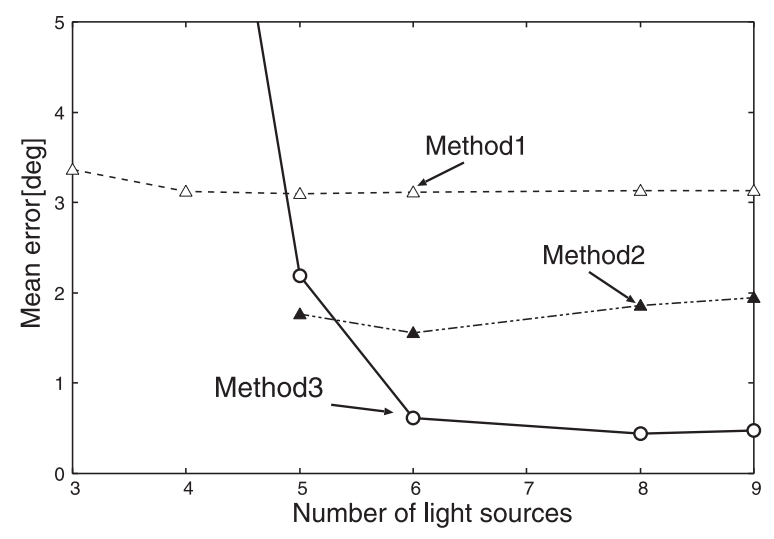

Fig. 9. Relation between mean error and number of light sources with each method in simulation.

が現れている。一方，提案手法では多少の誤差は見られる が，手法 2 に比べても十分誤差が小さいことが確認できる。

また, 光源数と誤差の関係を Fig. 9 に示す。光源数を 3 から 9 個まで増やした場合の, 各手法に扔ける誤差を示し ている。手法 2 は光源数が 5 個以上でないと適用できない アルゴリズムであるので，光源数が 5 個以上で検討した。

手法 1(Method1) の最小二乗法だけを用いた手法では， 不適光源が一つと考えれば，光源数が増えるにつれて鏡面 反射の影響が少なくなると期待されるが，実際は光源数が 増えるにつれ不適光源数も増加することになり，誤差はそ れほど小さくならない。手法 $2(\operatorname{Method} 2)$ の最大值，最小 值を除く手法でも, 上記の理由と同じで, 光源数が増加する につれて誤差が増えている。しかし，提案手法 (Method3) では, 6 光源以上で顕著に誤差が小さくなっている。 5 光 源以下では, どの光源においても影となってしまう領域が 多く存在し, 提案手法では, 影の部分 (著しく輝度值が低 い) の法線を求められず，逆に誤差が大きくなっている。

以上のことより, 本提案手法では, 光源数 6 個以上にお いて, 他の手法よりも十分小さい誤差で法線べクトルの推 定が可能であることが分る。

\section{4. 実 験}

$\langle\mathbf{4} \cdot \mathbf{1}\rangle$ 撮影条件 実験における撮影条件は前述の Fig. 4 と同様である。物体としては, 半径 $44[\mathrm{~mm}]$ のソフ トビニール製の緑色ボールを対象とし理想的な球と仮定し た。光源数は 8 光源とし, 照度差ステレオ法では光源から の光は平行光を仮定しているため, 物体に対して十分離れ た位置に光源を配置した。物体から各光源までの距離は約 $1.6[\mathrm{~m}]$ とし, 光源の配置は Fig. $5(\mathrm{e})$ の 8 光源に抒ける配 置とした。光源としては， $60 \mathrm{~W}$ のレフランプを使用し，そ れぞれの画像のヒストグラムょり，球の領域がほぼ同じ明 るさになるように，距離を微調整した。

物体の画像は，カメラに対して平行射影を仮定している ため, カメラの位置もできる限り物体から遠い位置とし， $0.6[\mathrm{~m}]$ の位置に固定した。カメラにはディジタルカメラ

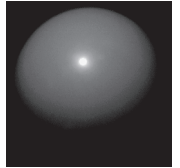

(a) $\beta=112.5$ [deg]

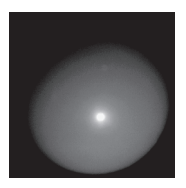

(e) $\beta=292.5$

[deg]

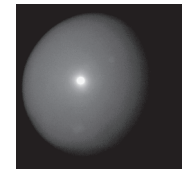

(b) $\beta=157.5$ [deg]

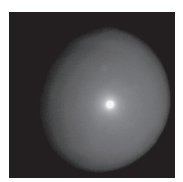

(f) $\beta=337.5$ [deg]

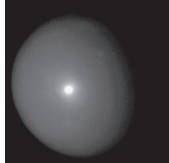

(c) $\beta=202.5$ [deg]

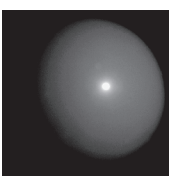

(g) $\beta=22.5$ [deg]

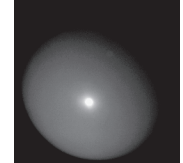

(d) $\beta=247.5$ [deg]

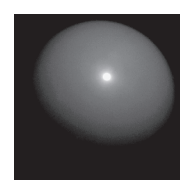

(g) $\beta=67.5$

[deg]
Fig. 10. Pictures of sphere provided specular surface with different light source direction in experiment.

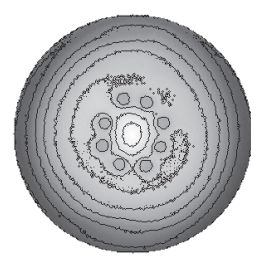

(a) Method1

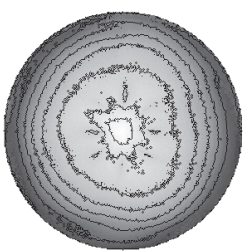

(b) Method2

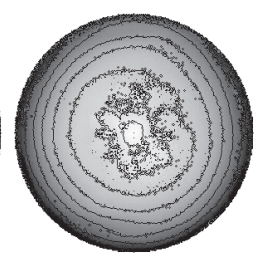

(c) Method3

$$
\begin{gathered}
0[\mathrm{deg}] \underset{\text { zenith angle }}{\stackrel{\rightleftarrows}{\rightleftarrows}} 90[\mathrm{deg}] \\
\text { of normal vector }
\end{gathered}
$$

Fig. 11. Distribution of zenith angle of estimated normal vector in experiment.

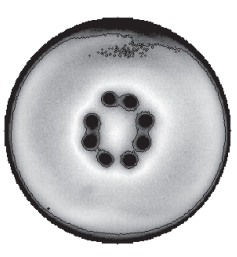

(a) Method1

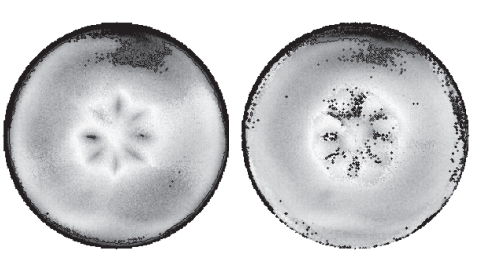

(b) Method2 (c) Method3

\footnotetext{
0 [deg] 20 [deg]

The angle between estimated normal vector and ideal normal vector.
}

Fig. 12. Distribution of angles between estimated normal vector and ideal normal vector in experiment.

OLYMPUS CAMEDIA C-3040を使用した。撮影された 画像サイズは 640x480[Pixel] である。シミュレーションの 場合と同様に, 最小二乗法だけ (手法 1 ), 最大と最小輝度 值を除く手法 (手法 2), 提案手法 (手法 3) の各手法で法 線べクトルの推定結果を比較した。また, 提案手法でのパ ラメータ空間は天頂角 $(0 \sim 90 \mathrm{deg})$ を 2 度毎に 45 段階, 方 位角 $(0 \sim 360 \mathrm{deg})$ を 10 度毎に 36 段階の $45 \times 36$ の空間と し投票を行った。多数決により選択された一点に所属する 法線ベクトルについて, 再度, 光源情報を使用した最小二 乗法によって法線ベクトルを求めた。

$\langle\mathbf{4} \cdot \mathbf{2}\rangle$ 実験結果 Fig. 10 に，実験で撮影された 8 光 
Table 1. Comparison of mean error and processing time.

\begin{tabular}{|l|c|c|c|}
\hline & $\begin{array}{c}\text { Mean } \\
\text { error [deg] }\end{array}$ & $\begin{array}{c}\text { processing } \\
\text { time[s] }\end{array}$ & $\begin{array}{c}\text { processing } \\
\text { time ratio }\end{array}$ \\
\hline Method1 & 8.676 & 0.125 & 1.000 \\
\hline Method2 & 8.272 & 1.391 & 11.128 \\
\hline Method3 & 7.044 & 2.765 & 22.120 \\
\hline
\end{tabular}

CPU:Intel CoreDuo 1.6GHz OS:Windows XP RAM:1GB

源による画像を示す。図に示すように鏡面反射を示す物体 を対象とした。各手法により推定された物体表面の法線べ クトルから天頂角を求め，その分布を示したものを Fig. 11 に，推定された法線べクトルと理論的に求められた法線べ クトルのなす角度の分布を Fig. 12 に示す。シミュレーショ ンの結果と比べると若干誤差が大きいものの，ほぼ同等の 結果が得られている。Fig. 11 より，手法 1 では，鏡面反射 の部分で誤差が大きいことが見てとれる。また，手法 2 と 手法 3 は，Fig. 11 では，両者の違いがはっきりしないが, Fig. 12 のように，内積の分布を見ると，本論文で提案した 手法 3 は手法 2 に比べて, 特に球の周辺部分, つまり影を 生じる部分において, 誤差が改善されていることがわかる。 Table 1 に各手法での平均誤差及び，表面法線べクトルを 求めるまでの計算時間を示す。実験においては，光源方向 の誤差, 光源の照明強度の不均一性, 環境光, カメラのノ イズ等の影響が考えられ，平均誤差はかなり大きな結果と なっている。しかし，各手法の平均誤差を比較しても，提 案手法が誤差を低く抑えることができることが分る。

Table 1 において, 各手法における, 表面法線べクトル を求めるまでの演算時間の比較も示している。手法 1 では, あらかじめ全ての光源方向べクトルから逆行列の演算をし ておき，各点の輝度值を基に計算を行っている。手法 2 で は，使用する光源の組合せが変化することから，各画素の 輝度值毎に逆行列の演算も含めて計算を行っている。使用 する光源の組合せ全てにおいて，あらかじめ逆行列を求め ておくことも可能であるが，今回は毎回逆行列の演算を行っ ている。手法 3 では, 使用する光源全ての組合せにおいて 法線ベクトルを求め, 天頂角, 方位角の空間に射影しピー クを求め,さらにピークを示した法線べクトルを得た時の 光源の組み合わせ全てを利用して，再度，最小二乗法で法 線ベクトルを求める演算を行っている。手法 1 の演算時間 を 1 とすると, 提案手法は約 22 倍の演算量になるが, 誤 差を十分小さく抑えることが可能であり, 計測に光走査を 必要とするレンジセンサ等を使用した手法や, 対応点探索 演算やオクルージョン問題を含む, 複数台のカメラを用い た受動型ステレオ法等，他の一般的な三次元形状計測手法 と比較しても，十分高速な計測が可能であると考えられる。 したがって，本提案手法は有効かつ有用な手法といえる。

\section{5. むすび}

本研究では, 照度差ステレオ法により物体表面法線ベク トルを求める際に，鏡面反射や影の影響を抑えるために，
多数 (6 個以上) の光源を用い投票 - 多数決のアルゴリズ ムに基づく新たな手法を提案した。鏡面反射の影響を受け た表面法線べクトルは, 影響のないものと比べてその方向 が大きく異なることから, 天頂角, 方位角のパラメータ空 間に投票した場合に，空間上に広く分布する。鏡面反射の 影響を受けない表面法線ベクトルは，空間上の 1 点に集約 される。したがって, 空間上で最も得票数の多い表面法線 ベクトルは鏡面反射の影響を受けていないとみなせる。本 提案手法により, 計算コストは増えるものの, 従来の手法 よりも誤差を低く抑えることに成功した。シミュレーショ ンや実験による検討によって, 本手法が従来手法に比べて 有効であることを確認した。なお, 本提案手法は, 光源位 置が既知であり各光源の明るさも一定であると仮定してい る。しかしながら, 実験においては, 光源の位置, 物体, 力 メラ位置等を正確に調整することは実質上難しく, これら の位置の誤差の影響は避けられない。光源位置に誤差が含 まれていると，パラメータ空間の一点に投票が集まらない 可能性がある。これは, 各光源の明るさの違いでも同様な ことが起こると考えられる。したがって，ノイズの影響を 受けやすい手法であると思われ，ノイズに対するロバスト 性の向上が重要な課題である。この課題に対しては，パラ メータ空間の分割領域を広げる等の対応が考えられる。実 験においても行っているが，パラメータ空間の分割数を小 さくし，鏡面反射の影響によって大きくべクトルが異なる ものだけを排除して，鏡面反射の影響の少ない光源だけを 使用し, 最小二乗法的に法線ベクトルを求めることで対応 している。また, 光源位置の校正手法や, 光源方向を未知 として, 画像から光源位置を推定する手法の導入等の対策 が考えられる。

(平成 20 年 4 月 16 日受付，平成 20 年 7 月 8 日再受付)

\section{文献}

(1) S. Iguchim and K. Sato: "3D Imaging techniques for measurement", SHOKODO. Co., Ltd (1990) (in Japanese) 井口征士 ·佐藤宏介：「三次元画像計測」, 昭晃堂 (1990)

(2) W.N. Martin and J.K. Aggarwal: "Volumetric descriptions of objects from multiple views", IEEE Trans. PAMI, Vol.5, No.2, pp.150-158 (1983)

(3) R.J. Woodham: "Photometric method for determining surface orientation from multiple images", Optical Engineering, Vol.19, No.1, pp139-144 (1980)

(4) S. Fukui, Y. Iwahori, R.J. Woodham, and A. Iwata: "Classification of surface curvature from shading images using neural network and illumination planning", Trance. IEICE, Vol.J83-D-II, No.2, pp.610-622 (2000) (in Japanese) 福井真二・岩堀祐之・ ロバート J. ウッダム・岩田彰：「ニューラル ネットワークとイルミネーションプランニングを用いた濃淡画像か らの曲面の分類」, 信学論, J83-D-II, 2, pp.610-622 (2000)

(5) E.N. Coleman and R. Jain: "Obtaining 3-dimensional shape of textured and specular surfaces using four-source photometry", Computer Graphic and Image Processing, Vol.18, pp.309-328 (1982)

(6) F. Solomon and K. Ikeuchi: "Extracting the shape and rouphness of specular lobe objects using four light photometric stereo", IEEE Trans. PAMI, Vol.18, No.4, pp.449-454 (1996)

(7) S. Barsky and M. Petrou: "The 4-source photometric stereo technique for three-dimensional surfaces in the presence of 
highlights and shadows", IEEE Trans. PAMI, Vol.25, No.10, pp.1239-1252 (2003)

(8) H. Rushmeier, G. Taubin, and A. Gueziec: "Applying shape from lighting variation to bump map capture", Eurographics Rendering Workshop, pp.35-44 (1997)

(9) J. Sun, M. Smith, L. Smith, S. Midha, and J. Bamber: "Object surface recovery using a multi-light photometric stereo technique for non-lambertian surfaces subject to shadow and specularities", Image and Vision Computing, Vol.25, No.7, pp.1050-1057 (2007)

（10） 徐 剛・过 三郎：「3 次元ビジョン」, 共立出版 (1998)

(11) S. Tominaga and S. Ohhashi: "A color reflection model for object surfaces", Trans. IPS. Japan, Vol.33, No.1, pp.37-45 (1992) (in Japanese)

富永昌治・大橋伸一郎：「物体のカラー反射モデル」, 情処学論, 33 1, pp.37-45 (1992)

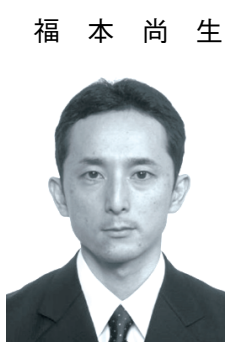

(正員) 1973 年 11 月 5 日生。 2002 年 3 月佐 賀大学大学院工学系研究科博士後期課程修了。同 年 4 月佐賀大学大学院工学系研究科生体機能 ステム制御工学専攻助手。2007 年 4 月同助教。 現在に至る。旧姓は徳島。細胞計測システム, コ ンピュータビジョン, 生体信号処理に関する研究 に従事。博士 (工学)。計測自動制御学会, 電子情 報通信学会, 日本生体医工学会, 日本サイトメト

リー学会各会員。

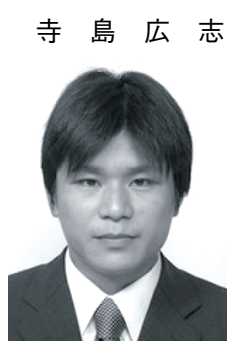

(非会員) 1985 年 2 月 20 日生。 2007 年 3 月佐 賀大学理工学部電気電子工学科卒業。同年 4 月佐 賀大学大学院工学系研究科博士前期課程生体機能 システム制御工学専攻入学。現在に至る。照度差 ステレオ法による物体形状復元の研究に従事。
相 知 政 司（上級会員） 1964 年 12 月 8 日生。 1989 年 3 月

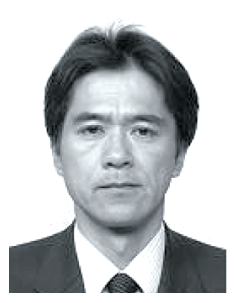
長崎大学大学院工学研究科修士課程修了。同年 4 月 NTT に入社。1 1991 年 4 月佐賀大学理工学部 助手。1993 年 4 月同電子工学科助手へ配置替。 2000 年 4 月同講師。 2002 年 1 月同助教授。 2008 年 4 月千葉工業大学工学部電気電子情報工学科教 授。現在に至る。数值電界解析を応用した分布誘 電率推定に関する研究並びに計算機応用工学に関 する研究に従事。博士 (工学)。計測自動制御学会, 電子情報通信学会, 日本シミュレーション学会会員。

古川達 也（正員） 1956 年 6 月 21 日生。 1984 年 3 月九

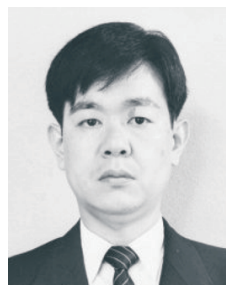
州大学大学院工学研究科博士後期課程単位取得退 学。同年 4 月長崎大学工学部助手。1986 年佐賀 大学理工学部電気工学科講師。1987 年同助教授。 1993 年 4 月同電子工学科助教授へ配置替。 2001 年 4 月電気電子工学科教授。現在に至る。数值解 析, 計算機応用工学に関する研究に従事。工学博 士。計測自動制御学会, 日本シミュレーション学 会, 日本 AEM 学会, 電子情報通信学会, 情報処理学会会員。 